\title{
Effect of Irrigation Water Types and Spraying With Seaweeds on Vegetative Growth, Biochemical Attributes and Minerals Contents
}

\section{of Ziziphus mauritiana and Citrus sinensis Seedlings}

Abbas, Karima F. ${ }^{1}$; Khawla H. Mohamad ${ }^{2}$ and Salwa J. Fakher ${ }^{3}$

${ }^{1}$ Kerbala University, College of Applied medical Science, Department of Environmental health.

${ }^{2}$ Basrah University, College of Agriculture, Department of Horticulture and Landscape.

${ }^{3}$ Basrah University, College of Agriculture, Department of Soil Sciences and Water Resources.

Received on: 18/9/2016

Accepted for publication on: 27/9/2016

\begin{abstract}
This experiment aimed to investigate the effect of the different irrigation water sources and spraying with seaweeds on the seedlings of two plants one is saltsensitive (Citrus sinensis) and the other is salt-tolerant (Ziziphus mauritiana) through studying growth parameters, as well as biochemical attributes and minerals in leaves of the studied plants. Four treatments were used for irrigation water as follow: (W1)The Tap Water (control) E.c $=1.2 \mathrm{dS} . \mathrm{m}^{-1}$, (W2) Shatt al-Arab river (sub river) $\mathrm{Ec}=5.2 \mathrm{dS} . \mathrm{m}^{-1}$, (W3) Shatt al-arab river (main) $6.2 \mathrm{dS} . \mathrm{m}^{-1}$,

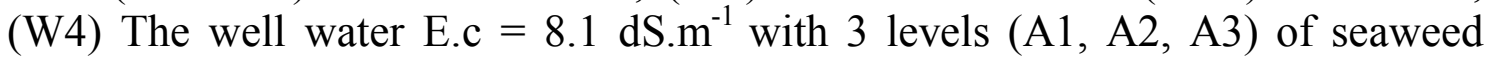
treatments prepared from (Agrosign marine) in the concentration of $(0,2,4 \mathrm{ml}$ /L), The results explained that there is a decrease in all parameters in this study with increasing the salinity of irrigation water and this is represented in well water irrigation as compared with another water types, while the interaction withseaweeds treatments caused significant increases in the growth parameters, biochemical attributes and minerals contents. This promotion was associated with increasing the concentrations to $(4 \mathrm{ml} / \mathrm{L})$, Which gave $42.94 \mathrm{~cm}$ in plant height, 2.00 number of shoots, 24.61 in the number of leaves, 5.34 in stem diameter, $101.2 \mathrm{~g}$ in fresh weight and $19.02 \mathrm{~g}$ dry weight. On the other hand the interaction with seaweed extract increased significantly growth parameters, attributes biochemical and mineral content, it gave the highest value A3W1 which was 3.48 $\mathrm{mg} / \mathrm{g}$ in the total chlorophyll and $73.82 \mathrm{mg} / \mathrm{g}$ in total carbohydrates, while the lowest at A1W4 which was $1.38 \mathrm{mg} / \mathrm{g}$ in the total chlorophyll and $42.92 \mathrm{mg} / \mathrm{g}$ in the total carbohydrates. The activities of the enzymes superoxide dismutase (SOD), peroxidase (POD) and catalase (CAT) have shown a marked increase when increasing the level of salinity in irrigation water as well as, the seaweeds extraction caused increasing in the content of these enzymes. The treatment (A1W4) gave the highest enzymes activities CAT, SOD, BOD which was 24.10, 21.83 and $7.93 \mathrm{u} / \mathrm{g} / \mathrm{f} . \mathrm{w}$ respectively.
\end{abstract}

Keywords: Irrigation water, salinity, seaweeds, minerals contents, antioxidant enzymes, Citrus sinensis, Ziziphus mauritiana

\section{Introduction}

Water is very necessary for growth and development of the plants. In fact, the global infrequency of water resource and increasing the salinity of soil and water which considered as one of the most important factors of irrigation water (Beltran, 
1999) that appeared on the last years and it can be seen obvious in Iraq .It is known that the Downfall of Sumer civilization about 4000 years ago was caused by unsuitable agricultural techniques, that's led to soil salinization and descent in the agricultural yield in the area (Pitman and Lauchli, 2002). Currently, the decrease of water levels in Tigris, Euphrates and shatt-alarab rivers in Iraq create a big problem that's lead to use other sources like wells water. Water quality can vary from source to source. Three sources of water are commonly used in the region of this study: municipal water, rivers and well water. Well water frequently contains high levels of dissolved elements, and classified as a saline water while thewater obtained from rivers or lakes commonly has a lower level of dissolved chemicals than well water. In general, salinity is considered as a one of the major severe abiotic stress factors that effects on plant metabolism by inducing decreases in soil water potential, which leads to adisturbance in water uptake by roots. Overall, Plants vary greatly in their ability to tolerate salt in water and classified into the sensitive plants to the salinity in spite of the difference among the species for the range of salinity tolerance degree like citrus (Mass,1996; Murkute et al., 2005) and halophytes, which are able to grow at high concentrations of salt, like Ziziphus (Flowers and Colmer, 2008).

\section{Ziziphus mauritiana Lam} (Rhamnaceae) has marked ability to tolerate salt stress and drought (Bhatt et al., 2008), while the citrus (Rutacea), are especially more sensitive to salinity than other plant (Boman,
1993; Maas, 1993). Current studies have focused on finding substitute natural solutions that will work to prevent and reduce the risk of salinity on plant, one of these processors are adding the seaweeds (Agrosign marine), that stimulate plant growth (Zodape, 2001; Strick et. al., 2003). It contains all major and minor nutrients including macro and micro elements ,amino acids and fatty acids and plant growth regulator like auxin, gibberllins and cytokinin. Seaweed extracts have been reported to stimulate the growth and yield of plants, develop tolerance to environment stress, increase nutrient uptake from soil and enhance antioxidant properties (Rathore, 2009). This work aimed to investigate the effect of various kinds of irrigation water on tolerant plant Ziziphus mauritiana and sensitive plant Citrus sinensis and increasing the tolerance to salinity by spraying the seaweeds.

\section{Materials and Methods}

This study was conducted in the Horticulture Department, Agriculture College, Basrah University, Basrah, Iraq from 17 November to 17 April, 1916 .The experiment was designed according to completely randomized Block design (RCBD), as a factorial experiment with three factors (Irrigation water, Seaweed Liquid extraction and plant types) four time replication, The experiment consisted of 96 plastic pots $(29 \mathrm{~cm}$ diameter), containing one year -old seedlings of same size and length taken for both experimental plants previously characterized as salt-tolerant Ziziphus mauritiana cv. Tuffahi (P1) and salt-sensitive Citrus sinensis $\mathrm{cv}$. local (P2), (an experimental unit was one plant in one pot). Ir- 
rigation water salinity treatment were applied as:

1. The tap water ( control) (W1) $\mathrm{Ec}=1.2 \mathrm{dS} . \mathrm{m}^{-1}$

2. Shatt al-arab river (sub river) (W2) $\mathrm{Ec}=5.2 \mathrm{dS} \cdot \mathrm{m}^{-1}$

3. Shatt al-arab river (main) (W3) $=6.2 \mathrm{dS} . \mathrm{m}^{-1}$ $\mathrm{dS} . \mathrm{m}^{-1}$

4. The well water (W4) Ec $=8.1$

Seaweed liquid fertilizer was prepared from (Agrosign marine, it consist of organic matter extracted from seaweeds $12 \%$,fatty acids group $65 \%$, natural growth regulators 25 ppm, potassium 3\%, phosphor $2 \%$,nitrogen $15 \%$ ) with three levels $(\mathrm{A} 1=0, \mathrm{~A} 2=2, \mathrm{~A} 3=4 \mathrm{ml} / \mathrm{L})$, The solutions were sprayed once on the leaves in the early morning, every 20 days. At the end of experiment the plants were harvest and washed with distilled water then the morphological parameters were taken such us Plant height $(\mathrm{cm})$, Number of shoots, number of leaves, stem diameter $(\mathrm{mm})$, fresh and dry weight (gm). then dried by freeze dryer. Total chlorophyll was determined according to Goodwin (1976), total carbohydrates was determined according to Dobois et al., (1956), The shoot dry matter was grunden, $\mathrm{Zn}^{+2}$ and $\mathrm{Fe}^{+2}$ were determined by Atomic Absorption Spectrophotometer after digested the samples in $\mathrm{HNO}_{3}$ and $\mathrm{HCIO}_{4}$ as pointed out in A.O.A.C.(1984), the $\mathrm{N}$ content was determined by micro Kjeldahl method (Bremner and Mulvaney, 1982), $\mathrm{k}$ by flame photometer, and $\mathrm{P}$ by spectrophotometer, after di- gestion in $\mathrm{H}_{2} \mathrm{SO}_{4}$ and $\mathrm{HCIO}_{4}$ (Jackson,1958). antioxidant enzymes extraction was accomplished by weighing $0.3 \mathrm{~g}$ from leaves were collected after 3 months were directly dry frozen. The frozen tissues were pestled in a cold mortar condition. A $6.0 \mathrm{~mL}$ solution containing $50 \mathrm{mM}$ potassium phosphate buffer ( $\mathrm{pH} 7.0), 0.1 \mathrm{mM}$ EDTA, 4\% polyvinyll phrolidone (PVP) and $0.2 \mathrm{mM}$ ascorbic acid. The extract was centrifuged at $12,000 \mathrm{x} \mathrm{g}$ at $4{ }^{\circ} \mathrm{C}$ for $20 \mathrm{~min}$ for purification. The enzyme assays were represented in supernatant. The CAT activity was measured as the change in absorbance of the reaction mixture at $240 \mathrm{~nm}$ due to hydrogen peroxide reduction (Aebi, 1984). It was calculated by the coefficient for $\mathrm{H}_{2} \mathrm{O}_{2}$ at $240 \mathrm{~nm}$ (40 $\mathrm{mM} \mathrm{cm})$. Determination of peroxidase POD activity was determined according to Kar and Choudhuri (1987) method. Activity unit was calculated using the coefficient of absorbance for tetraguaiacol at $470 \mathrm{~nm}$ (22.6 mM). POD activity was expressed as enzyme units per gram fresh weight $(\mathrm{U} / \mathrm{g}$ fw). Superoxide dismutase (SOD) activity was determined according to Giannopotitis \& Ries (1977), The absorbance readings were taken at wave length of $560 \mathrm{~nm}$. One unit of SOD activity was defined as the enzyme activity that reduced the photo reduction of nitroblue tetrazolium to blue formazan by $50 \%$. SOD activity was expressed as enzyme units per gram fresh weight (U/g fw). 
Table 1. Some physical and chemical characters for the studied soil.

\begin{tabular}{|c|c|c|}
\hline Soil separates & $\mathbf{\%}$ & \multirow{2}{*}{ Texture } \\
\hline Sand & 14.10 & \multirow{2}{*}{ Mixture } \\
\hline Silt & 48.40 & \\
\hline Clay & 37.50 & Value \\
\hline Chemical characters & Units & 2.8 \\
\hline Electrical Conductivity(EC) & $\mathrm{dS} \cdot \mathrm{m}^{-1}$ & 7.95 \\
\hline $\mathbf{p H}$ & - & 0.85 \\
\hline Organic matter $_{\text {Soluble ions }}$ & & \\
\hline Soluble Ca $^{++}$ & $\mathrm{gm} .100 \mathrm{gm}^{-1}$ & 7.05 \\
\hline $\mathbf{M g}^{++}$ & $m m o l . L^{-1}$ & 6.45 \\
\hline $\mathbf{N a}^{+}$ & $m m o l . L^{-1}$ & 4.62 \\
\hline $\mathbf{K}^{+}$ & $m g . L^{-1}$ & 12.08 \\
\hline $\mathbf{H C O 3}^{-}$ & $\%$ & 20.80 \\
\hline $\mathbf{C l}^{-}$ & $m m o l . L^{-1}$ & 7.32 \\
\hline $\mathbf{S O 4}^{=}$ & $m m o l . L^{-1}$ & 9.86 \\
\hline
\end{tabular}

Table 2. Some chemical characters for the studied irrigation water types .

\begin{tabular}{|c|c|c|c|c|c|}
\hline & Units & (W1) & (W2) & (W3) & (W4) \\
\hline pH & - & 7.12 & 6.85 & 6.32 & 6.16 \\
\hline E.Ce & dS. $m^{-1}$ & 1.2 & 5.2 & 6.2 & 8.1 \\
\hline $\mathrm{Cl}^{-}$ & mmol. $L^{-1}$ & 4.71 & 13.15 & 19.23 & 23.16 \\
\hline Soluble $\mathbf{C a}^{++}$ & Mmol. $L^{-1}$ & 4.91 & 14.82 & 21.78 & 24.64 \\
\hline Soluble $\mathbf{M g}^{++}$ & Mmol. $L^{-1}$ & 7.85 & 22.57 & 25.97 & 32.85 \\
\hline Soluble $\mathbf{K}^{+}$ & Mmol. $L^{-1}$ & 0.15 & 0.26 & 0.28 & 0.38 \\
\hline Soluble $\mathbf{N a}^{+}$ & Mmol. $L^{-1}$ & 3.56 & 13.30 & 20.32 & 29.81 \\
\hline
\end{tabular}

\section{Results}

Growth parameters: When evaluating the data of research recorded in Table (3), it is clear that different water types play an important role in plant growth with the four types of water, The results showed a significant decline in the average of growth parameters (plant height, number of shoots, number of leaves, stem diameter, fresh and dry weight). The decrease in growth parameters appeared with well water compared to tap water that having the highest value, and this effect was more obvious in the salt sensitive plant (citrus seedlings), while the Ziziphus seedlings were exceed in growth parameters values. On the other hand, there are many significant differences ap- peared when treated with seaweeds compared with untreated seedlings the highest value was represented by the treatment A3W1 which were $62.33 \mathrm{~cm}$ for plant height, 4.83 for number of shoots, 40.50 for number of leaves and 7.26 for stem diameter.

Biochemical attributes: The data of biochemical attributes are presented in Table 4 There were significant differences between treatments in total chlorophyll content and total carbohydrates, The highest value was found at treatment $\mathrm{A} 3 \mathrm{~W} 1$ for both plants which was $3.48 \mathrm{mg} / \mathrm{g}$ in the total chlorophyll and $73.82 \mathrm{mg} / \mathrm{g}$ in total carbohydrates, while the lowest at A1W4 which was $1.38 \mathrm{mg} / \mathrm{g}$ in the total chlorophyll and $42.92 \mathrm{mg} / \mathrm{g}$ in the total carbohydrates. On the other 
hand, it is clear from the present results that the activities of the three important anti oxidative enzymes were increased significantly with increasing the salinity of irrigation water. It was observed that the activities of CAT, BOD and SOD were increased at well water, but the lowest value in tap Water. In addition, the seaweeds raised the activities of antioxidative enzymes in Ziziphus seedlings as compared with citrus seedlings. The treatment (A1W4) gave the highest enzymes activities CAT, SOD, BOD which was $24.10,21.83$ and $7.93 \mathrm{u} / \mathrm{g} / \mathrm{f} . \mathrm{w}$ respectively.

Minerals content: A negative relationship was appeared in $\mathrm{N}, \mathrm{P}, \mathrm{k}$, $\mathrm{Zn}, \mathrm{Fe}$ content in seedling leaves for both plants with increasing water salinity, While The interaction between concentrations the seaweeds and irrigation water types gave significant differences in minerals content. The highest value of minerals were at treatment A3W1 Table (5), which were $3.03 \%, 1.22 \%, 1.66 \%, 77.21$ $\mu \mathrm{g} / \mathrm{g}, 60.39 \mu \mathrm{g} / \mathrm{g}$ for in $\mathrm{N}, \mathrm{P}, \mathrm{k}, \mathrm{Zn}$, Fe content respectively.

\section{Discussion}

high-quality plants can be produced only by using high-quality irrigation water. There are local differences in water characteristics with the source of the water, After analyzing the results from the experiment, the plants of this study responded significantly to the types of irrigation water, and indicated that the seedling growth was reduced at well water which has a high salinity comparing with tap water, this decrease due to the high ions concentration accumulation in the soil solution which may influ- enced on the enzymes activation inside the plant cells by modulating the active sites of enzymes also the $\mathrm{H}^{+}$ATP ase pumps may stop working or the membranes may be impaired, that affect the permeability as well as the salinity affected on the Photosynthesis, respiration processes and electron transport chains (Orcutt and Nilsen,2000). There is an imbalance of nutrients due to the factor involved in the salt-induced inhibition in photosynthesis and subsequently in plant growth reduction. We found that the type of water treatments play an important role in altering the mineral nutrient distribution and decreased the absorption rates, different researchers reported that the increasing salinity of water has effects on some traits of growth and yield (Hamaad et. al., 2013; Hirich et. al., 2014; Algosaibi et. al., 2015) and reduced $\mathrm{Zn}, \mathrm{Fe}$ accumulation (Bhatt et. al.,2008). The antioxidant enzymes were raised positively with increasing of salt concentration in irrigation water and this activation may occur due to the excessive generation of reactive oxygen species (ROS) such as superoxide and hydroxyl radicals that are concede red as a one corollary of a biotic stress exactly as high salinity and cellular homeostasis (Mittler 2002). ROSs may have the ability to interact with many cellular components, and may result in significant damage to cell structures. When ROS increases, chain reaction start, in which superoxide dismutase (SOD) catalyzes the dismutation of $\mathrm{O} 2$ - radical to molecular $\mathrm{O} 2$ and $\mathrm{H} 2 \mathrm{O} 2$ (Meloni et. al., 2003). 
The $\mathrm{H} 2 \mathrm{O} 2$ is then detoxified in the ascorbate-glutathione cycle (Mittler 2002), which involves the oxidation and re-reduction of ascorbate and glutathione through the ascorbate peroxidase (APX) and glutathion reductase (GR) enzymes (Noctor \& Foyer 1998). If there is an imbalance in the cell compartment between the production of reactive oxygen species (ROS) and antioxidant defense, oxidative stress and damage occurs (Mittler 2002), many researchers reported that, (Maia et. al., 2010; Kahrizi et. al., 2012)

On the other hand, the interaction of irrigation water type and spraying with seaweeds gave the plants the ability to tolerate the salinity stress especially the plants which were irrigated with well water, compared with the untreated plants That maybe because the sea weeds could enrich the nutrients contents of the soil and is probably due to the presence of growth promoting hormones and nutrients in more quantities. The salinity of water stimulated the decreasing of leaf chlorophyll through embarrassment of chlorophyll synthesis or accelerated degradation has been well explained by Reddy and Vora (1986),and this reverberated on total carbohydrates content. Different researchers reported that the treatmentbyseaweed caused substantial increase in growth (Thirumaran et. al., 2009; Taha and Salih,2012; Abdul-Jabar et. al., 2012 ; Hamaad et. al., 2013;)An attention-grabbing observation that there is a relatively salt tolerance in Ziziphus seedlings more than Citrus seedling, It is well known that most crops are salt sensitive or hypersensitive (glycophytes) on the contrary to halophytes that have the capacity to accommodate severe salinity because of the very special anatomical and morphological adaptations or avoidance mechanisms (Flowers et al., 1986). These are relatively unique characteristics for which the genes are not likely to be introgressed easily into crop plant (Yokoi et al.,2002). From our study we can conclude that, the increasing of salinity of irrigation water over 5 $\mathrm{dS} . \mathrm{m}^{-1}$ has a negative influence and reduction in growth parameters ,biochemical attributed and minerals contents. Also, the spraying with seaweeds act as a bio stimulator, reduce from the effects of salinity in irrigation water and encourage the plants to resist a bio stress like salinity, furthermore, type of plant play an important role in the tolerance toward salinity according to irrigation waters types, the result shows that Ziziphus showed obvious tolerance compared with citrus seedling which is concedered a sensitive plant .

\section{References}

A.O.A.C.(1984). Official Method of Analysis, 14 eds. Williams S, ed. Arlington, VI.

Abdul-Jabar, A.S.; H. S. AL-Rashedy and M. A. AL-Ubeidi (2012). Effect of the Different Seaweed Extract (Seamino) Concentrationson Growth and Seed Chemical Composition of Two Wheat Varieties. Mesopotamia J. of Agric. Vol. 23 No. 1: $100-113$.

Aebi H (1984). Catalase in Vitro. Method Enzym 105: 121-126.

Algosaibi, A. M., M.M. El-Garawany, A. E. Badran and A. M. Almadini (2015). Effect of Irrigation Water Salinity on the Growth of Quinoa Plant Seedlings. Journal of Agri- 
cultural Science; Vol. 7, No.8.pp: 205-214.

Beltran, J.M. (1999). Irrigation with saline water: Benefits and environmental impact. Agric. Water Manag., 40,183-194.

Bhatt, M.J, Patel, A.D, Bhatti, P.M., Pandey A.N.(2008). Effect of soil salinity on growth, water status and nutrient accumulation inseedlings of Ziziphus mauritiana (Rhamnacea). - J. FruitOrnam. Plant Res. 16: 83-401.

Boman, B.J. (1993). First-year response of 'Ruby Red' grapefruit on four root stocks to fertilization and salinity. Proceed. of the FloridaStateHort. Soc.., 106: 12-8.

Bremner, J.M. and C.S. Mulvaney, (1982). Nitrogen-total. pp: 595624 In A.L. Page et al. (ed.) Methods of soil analysis. Part 2. 2nd ed. Agron. Monograph 9. ASA and SSSA, Madison, WI.

Dobois, M. K., K. A. Crilles, J. K. Hamiltor, D. A. Rebers and F. Smith (1956). Colorimetric method for determination of sugars and substance. Anal . Chem., 28: 350-365.

Flowers, T.J, T.D. Colmer (2008). Salinity tolerance in halophytes. New Phytol,179:945-963.

FlowersTJ, MA. Hajibagheri, NJW Clipson.(1986). Halophytes. The Quarterly Review of Biology 61, 313-337.

Giannopotitis C. N. and S. K. Ries (1977). Superoxide dismutase in higher plants. Plant Physio 159: 309-314.

Goodwin, T.W. (1976). Chemistry and Biochemistry of Plant Pigment. $2^{\text {nd }}$ ed. Academic Press, London, New York., San Francisco, pp. 373.

Hamaad,H.S., D.A. Mohammed and A. A. Obaid (2013).Effect of Irrigation water salinity, magnetic and soaking by the ascorbic acid and seaweeds (oligo-x) on germination and seedling growth of hybrids Cucumber (Dalia)in protected environment. Diyala J. Agric. Sc., 5(2) 213-222.

Hirich, A., A. Jelloul, R. Choukr-Allah and S.E. Jacobsen (2014). Saline water Irrigation of Quinoa and Chickpea: Seedling. Rate, Stomatal Conductance and Yield Responses J. Agro Crop Sci. 200 (378-389).

Jackson, M. L.(1958). Soil chemical analysis. 1.ed. prentice-Hallinc, Englewood, Cliffs New Jersey.

Kahrizi, S, M. Sedghi and O. Sofalian (2012). Effect of salt stress on proline and activity of antioxidant enzymes in ten durum wheat cultivarsAnnals of Biological Research, 2012, 3 (8):3870-3874.

Kar P. K. and Choudhuri M. A. (1987). Possible mechanisms of light induced chlorophylleradication in senescencing leaves of hydrila veticillata. Physiol Plant 70:729-734.

Maia O. M., E.L. Voigt, C. E. C. Macêdo, S. 1. Ferreira-silva and J. A. G. Silveira (2010). Salt-induced changes in antioxidative enzyme activities in root tissues do not account for the differential salt tolerance of two cowpea cultivars.Braz. J. Plant Physiol., 22(1): 113-122.

Maas, E.V., 1993. Salinity and citriculture. Tree Physiol., 12: 195-216.

Meloni D. A., M. A. Oliva, C. A. Martinez and J. Cambraia (2003). Photosynthesis and activity of superoxide dismutase, peroxidase and glutathione reductase in cotton under saltstress. Environ Exp Bot 49:69-76.

Mittler R., (2002). Oxidative stress, antioxidants and stress tolerance. Trends Plant Sci.

Murkute AA, Sharma S, Singh SK (2005). Citrus in terms of soil and water salinity: a review. Journal of 
Scientific and Industrial Research 64:393 - 402.

Noctor, G. and C. H. Foyer(1998). Ascorbate and glutathione: Keeping active oxygen undercontrol. Annu Rev Plant Physiol Plant Mol Biol 49:249-279.

Orcutt, D.M., and E.T. Nilsen (2000). The physiology of plants under stress. USA.

Pitman MG. and A. Lauchli. (2002). Global impact of salinity and agricultural ecosystems. In: Salinity: Environment - Plants - Molecules, A. Lauchli and U. Lüttge (Eds.). Kluwer Academic Publishers, Dordrecht, pp. 3-20.

Rathore S. (2009). Effect of seaweed extract on the growth, yield and nutrient uptake of soybean (Glycine max) under rainfed conditions, South African Journal of Botany,75;351-355.

Reddy, M. P. and A. B. Vora (1986). Changes in pigment composition, hill reaction activity and saccharides metabolism in bajra (Pennisetum typhoides $\mathrm{S} \& \mathrm{H}$ ) leaves under $\mathrm{NaCl}$ salinity; Photosynthetica; 20:50-55.

Strick W.A.; M.S. Novak and J. Vanstaden. (2003). Cytokines in macro algae. Plant Growth USA: Association of Official Analytical chemists. Regul.41:13-24.

Taha, S. M. and L. M. Muhamad Salih (2012). Effect of Spry with Seaweed Extract (Matrix- 15) on Some Vegetative and Root Growth of two Strawberry Varieties (Fragaria X Ananasa Duch.) Journal of Kirkuk University for Agricultural Sciences. Vol. 3 (2):1-12.

Thirumaran, G.; M. Arumugam; R. Arumugam and $\mathrm{P}$. Anantharaman (2009). Effect of Seaweed Liquid Fertilizer on Growth and Pigment Concentration of Cyamopsis tetragonoloba (L)Taub. AmericanEurasian Journal of Agronomy 2 (2): 50-56.

Yokoi S., F.J. Quintero, B. Cubero, M.T. Ruiz, R.A. Bressan, P.M. Hasegawa, J.M. Pardo (2002). Differential expression and function of Arabidopsis thaliana NHX $\mathrm{Na}+/ \mathrm{H}+$ antiporters in the salt stress response. Plant J., 30:529539.

Zodape,S.T(2001). Seaweedsasfertilizer. J. Sci. Ind.Res.60(5):378-382. 
تأثير نوعية مياه الري والرش بمستخلص الأعشاب البحرية في النمو والصفات البايوكيميائية

و المحتوى المعدني لشتلات السدر Ziziphus mauritiana و البرتقال المحلي

\section{sinensis}

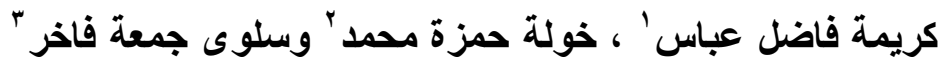

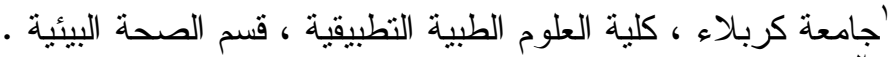

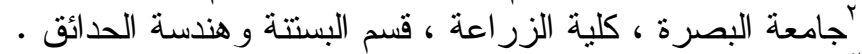

لجامعة البصرة ، كلية الزر اعة ، قسم التزبة و الموارد المائية .

أجريت هذه الدراسة لغرض معرفة تأثير نوعية مياه الري و الرش بمستخلص الاعـشئاب

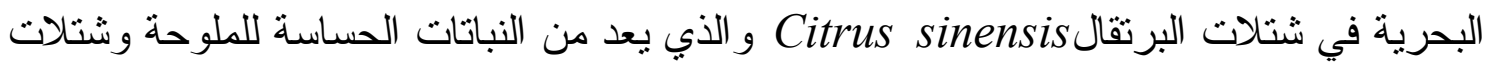

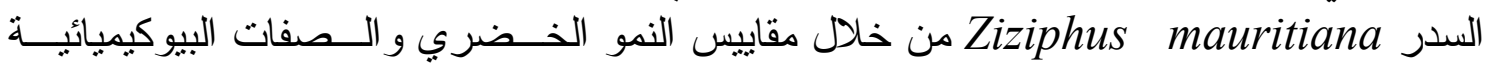

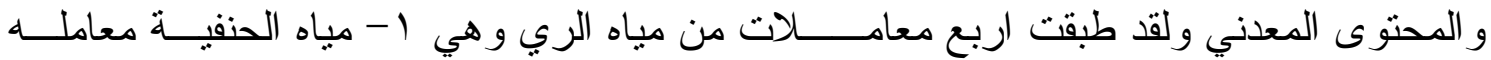

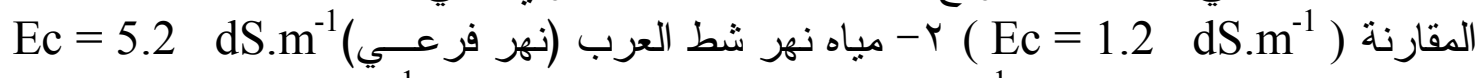

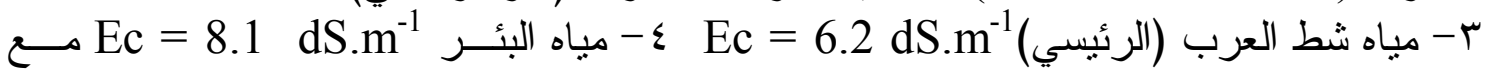

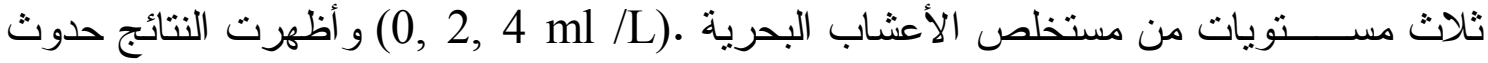

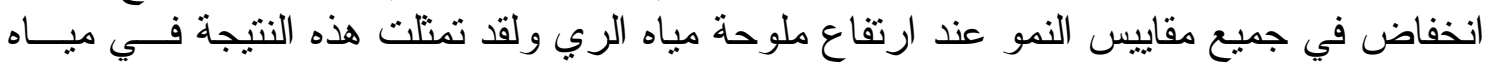
البئر مقارنة مع باقي أنو اع مياه الري و التي بلغت

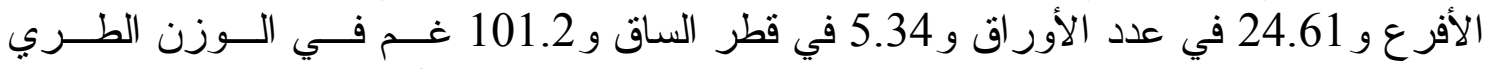

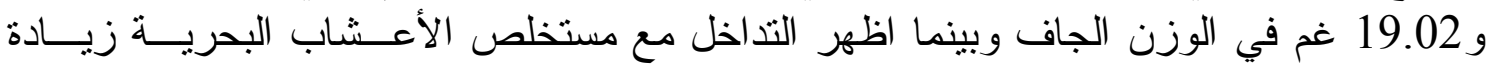

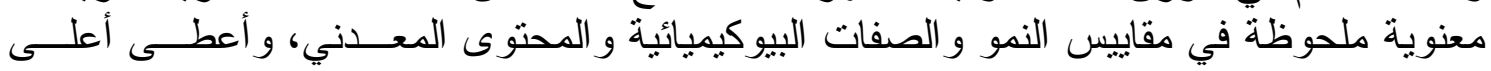

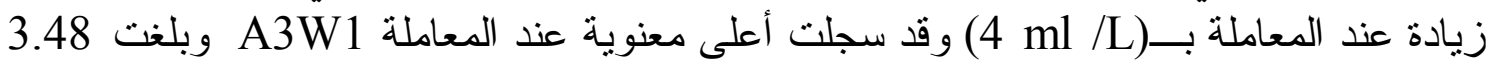

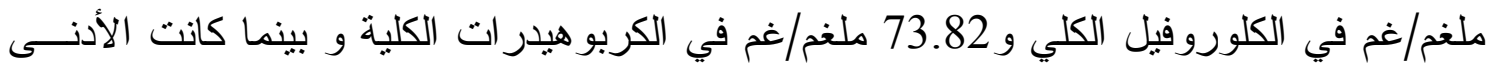

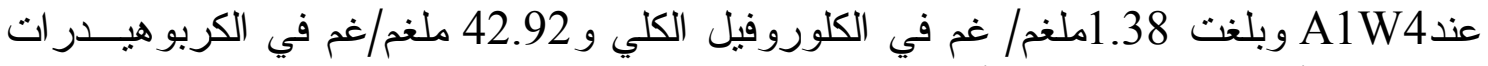

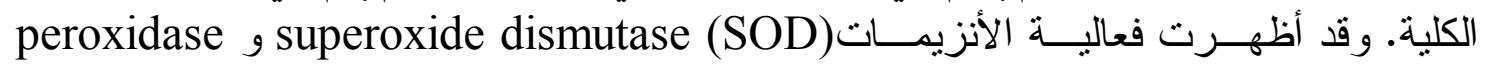

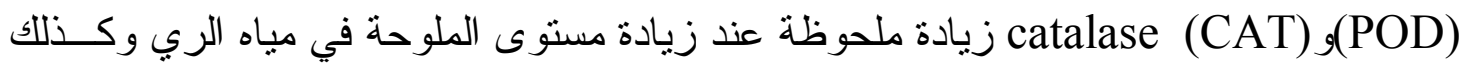

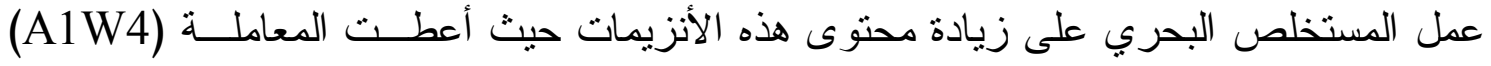

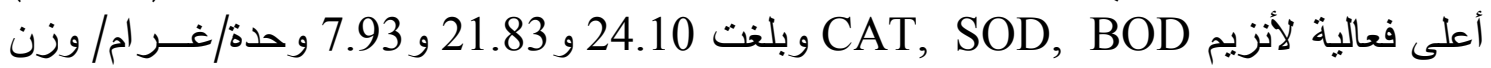

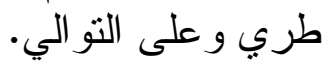

